DOI: http://doi.org/10.21009/JKKP.082.02

\title{
APAKAH PEMBELAJARAN JARAK JAUH MEMICU TERJADINYA CULTURE SHOCK PADA PESERTA DIDIK? SEBUAH STUDI LITERATUR
}

\author{
Dali Sofiatu Rohmah ${ }^{1}$, Ro'yal Aina ${ }^{2}$, Dimas Teguh Prasetyo ${ }^{3^{*}}$ \\ ${ }^{1,3}$ Program Studi Manajemen, STIE MNC Jakarta, 11520, Indonesia \\ ${ }^{2}$ Program Studi Akuntansi, STIE MNC Jakarta, 11520, Indonesia \\ "E-mail: dimasteguhprasetyo2394@gmail.com
}

\begin{abstract}
Abstrak
Pandemi covid-19 telah mengubah wajah pendidikan di Indonesia selama 2 tahun terakhir. Pola pembelajaran yang semula dilakukan secara tatap muka kemudian diubah menjadi pembelajaran jarak jauh. Pembelajaran jarak jauh masih menjadi solusi dalam melindungi peserta didik dari paparan covid-19 di tempat umum. Di sisi lain, pembelajaran jarak jauh memicu perasaan negatif dan mengurangi motivasi belajar. Fenomena culture shock atau gegar budaya diduga mampu menjelaskan perasaan dan pengalaman siswa selama pembelajaran jarak jauh. Penelitian ini menggunakan pendekatan kualitatif dengan analisis studi kepustakaan dari berbagai sumber ilmiah yang relevan. Studi ini dilakukan dalam rentang waktu Januari hingga Agustus 2021. Hasil tinjauan literatur dalam studi ini menunjukkan bahwa culture shock banyak dialami oleh peserta didik di segala rentang pendidikan (mulai dari siswa hingga mahasiswa) dan tidak dapat dihindari selama pembelajaran jarak jauh. Pembelajaran jarak jauh yang menuntut kemandirian ternyata turut berkontribusi pada motivasi belajar, penyesuaian diri, dan interaksi dengan lingkungan sekitar. Selama masa pembelajaran jarak jauh, culture shock banyak memicu penurunan motivasi dan perasaan negatif dalam proses pembelajaran. Untuk mampu mengurangi dampak yang muncul akibat culture shock, dukungan orang sekitar sangatlah diperlukan. Peran orang tua dan pendidik dinilai mampu menjaga peserta didik melalui fase culture shock selama pembelajaran jarak jauh di masa pandemi covid-19.
\end{abstract}

Kata Kunci: culture shock, pembelajaran jarak jauh, peserta didik

\section{Does Distance Learning Trigger Culture Shock in Students? A Literature Study}

\section{Abstract}

The covid-19 pandemic has changed the face of education in Indonesia over the past 2 years. The learning pattern that was originally carried out face-to-face was later changed to distance learning. Distance learning is still a solution in protecting students from exposure to covid-19 in public places. On the other hand, distance learning triggers negative feelings and reduces learning motivation. The phenomenon of culture shock or culture shock is thought to be able to explain students' feelings and experiences during distance learning. This study uses a qualitative approach with analysis of literature studies from various relevant scientific sources. This study was conducted in the period from January to August 2021. The results of the literature review in this study indicate that many students experience culture shock in all levels of education (from students to university students) and cannot be avoided during distance learning. Distance learning, which demands independence, contributes to learning motivation, adjustment, and interaction with the surrounding environment. During the distance learning period, culture shock often triggers a decrease in motivation and negative feelings in the learning process. To be able to reduce the impact that arises due to culture shock, the support of people around is very necessary. The role of parents and teachers is considered capable of keeping students through the culture shock phase during distance learning during the covid-19 pandemic.

Keywords: culture shock, distance learning, students

Received: 2021-10-13; Accepted: 2021-10-27 


\section{PENDAHULUAN}

Pandemi covid-19 yang terjadi pada awal tahun 2020 mendorong berubahnya konsep kehidupan oleh berbagai kebijakan yang mengakibatkan keterbatasan. Salah satu keterbatasan terjadi pada kegiatan pembelajaran. Pembelajaran yang semula dilakukan dalam ruang-ruang kelas secara tatap muka, kini sementara diubah menjadi Pembelajaran Jarak Jauh. Pembelajaran jarak jauh merupakan pembelajaran yang memanfaatkan teknologi multimedia, video, kelas virtual, teks online animasi, pesan suara, email, telepon konferensi, dan video streaming online. Pembelajaran ini dapat dilakukan secara masif dengan jumlah peserta yang tidak terbatas, bisa dilakukan secara gratis maupun secara berbayar (Bilfaqih \& Qomarudin, 2015).

Pembelajaran jarak jauh sebenarnya sudah diatur oleh Pemerintah Indonesia jauh sebelum pandemi covid-19. Dalam Undang Undang Republik Indonesia Nomor 20 Tahun 2003 tentang Sistem Pendidikan Nasional (Sisdiknas) bagian kesepuluh mengenai pembelajaran jarak jauh pasal 31, berbunyi: (1) Pembelajaran jarak jauh dapat diselenggarakan pada semua jalur, jenjang serta jenis pendidikan. (2) Pembelajaran jarak jauh berfungsi untuk memberikan layanan kepada kelompok masyarakat yang tidak bisa mengikuti pembelajaran secara tatap muka atau regular. (3) Pembelajaran jarak jauh diselenggarakan dengan berbagai bentuk dan cakupan yang didukung oleh sarana dan layanan belajar dan sistem penilaian yang menjamin mutu lulusan sesuai dengan standar nasional pendidikan. (4) Ketentuan mengenai penyelenggaraan pembelajaran jarak jauh sebagaimana dimaksud dalam ayat (1), ayat (2), dan ayat (3) diatur lebih lanjut dengan peraturan pemerintah. Dari peraturan tersebut, dapat dikatakan bahwa sebenarnya Pemerintah Indonesia telah memiliki alternatif pendidikan dalam konteks yang mungkin kurang ideal, seperti halnya pandemi covid19 yang membatasi pola pembelajaran tatap muka secara langsung.

Pembelajaran jarak jauh yang disebut sebagai solusi tepat dalam masa pandemi covid19 nyatanya tetap meninggalkan catatan serius. Dampak pembelajaran jarak jauh ternyata dirasakan oleh seluruh peserta didik di seluruh jenjang pendidikan (Zulela \& Primasari, 2021). Peserta didik dalam konteks ini bisa didefinisikan mulai dari siswa di jenjang Pendidikan Dasar, Pendidikan Menengah, Pendidikan Atas hingga mahasiswa di Perguruan Tinggi. Peserta didik yang bersekolah di pondok pesantren rentan kecanduan adiksi gawai selama pembelajaran jarak jauh (Deny, 2020; Dhini, 2021). Pada konteks pesantren juga ditemukan bahwa kurangnya interaksi antara pendidik dan santri hingga masalah jaringan menjadi kendala dalam pembelajaran jarak jauh (Hayato, 2020). Untuk membuktikan adanya dampak pembelajaran jarak jauh pada peserta didik di Indonesia selama masa pandemi covid-19, sebuah lembaga survei mencoba menelitinya. Hasilnya diketahui bahwa $92 \%$ peserta didik di Indonesia mengalami kendala selama penerapan pembelajaran jarak jauh (Saiful Mujani Research and Consulting, 2020). Terdapat sekitar 24\% warga tidak mempunyai akses internet, dan $76 \%$ memiliki akses internet. Selain itu, terdapat $67 \%$ masyarakat terbebani dengan biaya yang dikeluarkan pada saat pembelajaran jarak jauh selama pandemi. Survei tersebut juga selaras dengan studi terbaru. Dalam sebuah studi ditemukan bahwa peserta didik belum memiliki budaya belajar jarak jauh (Zulela \& Primasari, 2021). Peserta didik terbiasa berada di sekolah untuk melakukan kegiatan pembelajaran, berinteraksi dengan pendidik secara tatap muka dalam satu ruang yang sama dan juga bermain dengan temantemannya di sekolah.

Perubahan sistem pembelajaran menjadi pembelajaran jarak jauh menuntut peserta didik untuk dapat beradaptasi. Peserta didik memerlukan waktu untuk dapat menghadapi perubahan sistem pembelajaran yang secara tidak langsung akan berpengaruh terhadap daya serap belajar. Melihat fenomena tersebut, penulis menduga telah terjadi sebuah fenomena sosial culture shock pada peserta didik. Keinginan pergi ke sekolah, interaksi antar peserta didik ataupun dengan pendidik, belajar mandiri hingga bermain bersama yang tidak tercapai bisa menjadi salah satu gejala culture shock pada peserta didik. Hal tersebut diprediksi 
berkaitan dengan kemampuan penyesuaian diri serta berkorelasi dengan kurang optimalnya motivasi peserta didik dalam melakukan kegiatan pembelajaran. Untuk itu, studi ini ingin menelaah bagaimana fenomena culture shock terjadi pada peserta didik (siswa hingga mahasiswa) dalam proses pembelajaran jarak jauh selama pandemi covid-19 di Indonesia.

Culture shock atau yang dalam bahasa indonesia disebut sebagai gegar budaya merupakan suatu keadaan psikologis yang bersifat negatif, dimana individu sendiri merasa tidak mampu dalam menghadapi lingkungan budaya yang berbeda. Teori dari culture shock atau gegar budaya sendiri dicetuskan pertama kali oleh Hall (1959), yaitu dipandang sebagai gangguan akibat perbedaan suasana yang dihadapi di tempat asal menuju tempat baru dan asing (Maizan, 2020). Berkaitan dengan pernyataan tersebut, peserta didik mengalami gangguan belajar akibat perubahan suasana belajar yang dihadapinya. Dalam culture shock, individu merasa tidak mampu dalam menghadapi lingkungan budaya yang berbeda.

Studi-studi sebelumnya telah menelaah culture shock pada peserta didik dalam dalam konteks perubahan lokasi belajar. Pada studi kasus mahasiswa yang merantau, culture shock diketahui menjadi salah satu faktor yang berkontribusi kepada penyesuaian diri peserta didik (Siregar \& Kustanti, 2018). Meski relatif tidak memiliki pengaruh yang begitu besar, fenomena culture shock juga ditemukan dan berkorelasi dengan motivasi belajar mahasiswa (Basri \& Ridha, 2020). Tidak hanya itu, mahasiswa yang merasakan gejala culture shock ternyata merasakan penurunan kemampuan diri dalam bersosialisasi dengan lingkungan sekitar (Pramudina \& Setyorini, 2019). Namun, dalam konteks pembelajaran jarak jauh di tengah pandemi covid-19, penelitian sebelumnya lebih banyak mengulas gejala culture shock pada mahasiswa (Chafsoh, 2020; Muttaqin, et al., 2021; Ufairoh, Paraswati \& Nagari, 2021). Untuk melengkapi khasanah pengetahuan yang telah ada, studi ini akan mengeksplorasi fenomena culture shock pada peserta didik secara umum (mulai dari siswa hingga mahasiswa).

\section{METODE}

Studi ini disusun dengan menggunakan pendekatan kualitatif. Metode pengumpulan data yang digunakan yaitu analisis tinjauan literatur yang bersumber dari artikel ilmiah, berita di media massa, buku, dan sumber lain yang relevan. Dalam mempermudah pencarian literatur, peneliti juga menggunakan bantuan mesin pencarian Google Scholar dalam menemukan artikel ilmiah yang relevan. Pencarian artikel di Google Scholar menggunakan beberapa kata kunci, seperti culture shock, pembelajaran daring, motivasi belajar peserta didik, dan pembelajaran selama pandemi covid-19. Dalam studi ini, peneliti hanya fokus pada pembahasan peranan culture shock dalam proses pembelajaran jarak jauh pada peserta didik. Adapun studi ini disusun selama periode Januari hingga Agustus 2021.

\section{HASIL DAN PEMBAHASAN}

\section{Fenomena Culture shock pada Peserta Didik dalam Pembelajaran Jarak Jauh}

Fenomena pembelajaran jarak jauh menyebabkan peserta didik berada pada tahap krisis. Hal tersebut dapat ditandai dengan perasaan dendam dan jenuh yang disebabkan oleh kegiatan belajar mengajar yang secara signifikan mengalami perubahan dari tatap muka menjadi daring hingga metode hybrid terus berubah-ubah menyesuaikan kondisi yang terjadi. Hal ini tentu membuat peserta didik secara terus menerus harus menyesuaikan diri dan beradaptasi dengan suasana pembelajaran yang dilaksanakan. Tidak hanya itu, dunia digital dijadikan sebagai suatu alternatif dalam kegiatan pembelajaran jarak jauh yang menuntut seluruh instrumen dalam proses pendidikan harus mampu dan siap menggunakan teknologi. Sementara itu, tidak semua peserta didik ataupun orang tua sebagai pendukung mampu memfasilitasi dan menggunakan perangkat teknologi. Sehingga menyebabkan sulitnya peserta didik atau pun orang tua untuk mengenal pembelajaran online, metode pembelajaran serta tata cara pengumpulan tugas lewat media online (Astriani \& Marzuki, 2021). Hal inilah 
yang kemudian dapat menjadi akar dari munculnya problematika pembelajaran jarak jauh yang dapat memicu terjadinya culture shock pada peserta didik.

Culture shock dapat terjadi dalam lingkungan yang berbeda. Hal ini banyak dialami oleh para peserta didik yang mengalami perubahan kegiatan pembelajaran. Pada awalnya pembelajaran dilakukan secara tatap muka, kemudian pandemi covid-19 memaksa peserta didik dan harus berada dalam perubahan kegiatan belajar mengajar yang menjadi pembelajaran jarak jauh. Fenomena ini sejalan dengan studi sebelumnya yang menyatakan bahwa culture shock merupakan perasaan yang timbul disaat seseorang dihadapkan oleh lingkungan baru yang berbeda dengan lingkungan lamanya (Hutapea, 2014). Perasaan yang muncul meliputi rasa takut, perasaan tidak berdaya, merendahkan diri serta merasa tidak mampu dalam mengatasi tuntutan lingkungan. Perasaan tersebut dapat berpengaruh terhadap pola kehidupan individu, seperti gangguan tidur, gangguan pola makan, sulit untuk berkonsentrasi, dan mengalami stress berkepanjangan (Chafsoh, 2020).

Individu yang mengalami culture shock menampakan tidak adanya arah, tidak mengetahui hal yang sesuai dan tidak merasa sesuai pada budaya baru (Salamah, 2016). Culture shock biasanya dipicu oleh beberapa hal yaitu cues dan gangguan bahasa (Fuadi, 2018). Cues dapat berupa tanda, ekspresi wajah, gesture tubuh, atau kebiasaan yang digunakan sebagai petunjuk tentang bagaimana seseorang harus bertindak dalam situasi tertentu. Sedangkan gangguan bahasa terjadi secara sadar maupun tidak sadar yang kemudian mengakibatkan terputusnya komunikasi antar pribadi sehingga berdampak pada kecemasan dan rasa frustasi.

Individu yang mengalami culture shock akan menghadapi beberapa tahapan dalam pembentukan siklusnya. Devito (2013) berpendapat bahwa tahapan yang membentuk siklus culture shock diantaranya adalah pertama, tahap optimistik, pada tahap ini individu merasakan suatu pengalaman baru yang menarik, tahap ini berisi kegembiraan, serta rasa penuh harapan sebagai antisipasi memasuki lingkungan baru. Dalam hal ini peserta didik merasa antusias saat akan memasuki budaya baru dalam proses pembelajaran jarak jauh. Kedua, tahap krisis, pada tahap ini ditandai dengan suatu perasaan dendam, dan saat inilah terjadi culture shock. Pada tahap ini, peserta didik mulai merasa bosan terhadap pembelajaran jarak jauh. Sehingga timbul perasaan negatif yang memicu ketidakpatuhan terhadap kegiatan belajar. Ketidakpatuhan ini digambarkan lewat kegiatan belajar peserta didik yang malas dan kurang aktif.

Tahapan selanjutnya yakni tahap kesembuhan. Pada tahapan ini, individu yang mengalami masalah culture shock mulai mengerti mengenai budaya barunya dan dapat melampaui tahap sebelumnya. Peserta didik mulai paham, dan terbiasa dengan sistem pembelajaran jarak jauh. Keempat, tahap penyesuaian diri, pada tahap ini individu yang mengalami culture shock mulai mengerti dan mampu menghilangkan rasa cemas dalam dirinya. Peserta didik pada tahap ini sudah mampu menyesuaikan diri dengan kegiatan pembelajaran jarak jauh.

\section{Faktor yang Berkorelasi dengan Culture shock pada Peserta Didik dalam Pembelajaran Jarak Jauh}

Studi sebelumnya telah menyebutkan faktor-faktor yang dapat mendorong individu dapat merasakan culture shock. Mitasari \& Istikomayanti (2018) mengatakan bahwa fenomena culture shock dapat disebabkan oleh beberapa hal yaitu (1) ketegangan dalam penyesuaian psikologis; (2) merasa seolah-olah kehilangan teman, kehilangan status; (3) posisi personal, serta peranan sosial; (4) ketakutan akan ditolak oleh kebudayaan yang baru; (5) kebingungan dalam peran, identitas diri nilai dan perasaan, kecemasan dan keterkejutan dengan adanya kebudayaan berbeda, dan; (6) ketidakmampuan beradaptasi dengan lingkungan baru.

Culture shock juga terjadi karena perubahan perilaku. Perubahan perilaku ini dilihat berdasarkan gejala serta reaksi pada individu yang mengalami (Sinarti, 2017). Kehidupan pada saat pandemi merupakan suatu gejala baru dalam kehidupan peserta didik, sehingga perlu adanya penyesuaian bagi peserta didik. Dalam melakukan penyesuaian, mulai dari 
penyesuaian berkomunikasi, bersosialisasi, cara berpakaian serta kebiasaan lainnya pastinya memerlukan waktu yang cukup lama. Namun pada dasarnya peserta didik memiliki kemampuan dalam menyesuaikan diri, hanya saja setiap peserta didik memiliki kemampuan penyesuaian yang berbeda. Proses penyesuaian diri dipengaruhi oleh beberapa faktor, diantaranya adalah faktor personal, sosial, finansial dan edukasi (Mitasari \& Istikomayanti, 2018). Studi sebelumnya juga menyebutkan bahwa penyesuaian diri berkorelasi dengan stress (Erindana, 2021). Artinya, individu yang memiliki stres yang tinggi tentunya akan mengalami kesulitan dalam penyesuaian diri. Begitu sebaliknya, individu mempunyai stress relatif rendah tidak akan terlalu kesulitan dalam melakukan penyesuaian diri dengan lingkungan baru.

Asmuni (2020) menyebutkan beberapa problematika yang terjadi saat pembelajaran jarak jauh berlangsung diantaranya adalah; Pertama, terbatasnya fasilitas yang menunjang proses belajar peserta didik seperti smartphone, komputer maupun laptop. Kedua, jaringan internet yang seringkali mengalami gangguan, Hal ini membuat peserta didik kesulitan dalam menerima materi yang dijelaskan oleh peserta didik. Ketiga, ketiadaan kuota yang diperlukan untuk mengakses jaringan internet membuat proses belajar terhambat. Keempat, pembelajaran jarak jauh yang dilakukan di rumah membuat kondisi lingkungan belajar kurang kondusif, sehingga peserta didik tidak dapat berkonsentrasi dengan baik. Kelima, kesulitan dalam memahami materi, karena peserta didik harus belajar mandiri melalui pembahasan materi yang hanya diberikan dalam bentuk file. Keenam, peserta didik merasa bosan dan suntuk karena durasi pembelajaran yang terlalu lama. Selain itu, tugas yang diberikan kepada peserta didik juga terkadang sangat banyak dan sulit, sehingga membuat peserta didik kewalahan jika tidak mampu membagi waktu. Problematika yang terjadi inilah yang kemudian membuat kegiatan pembelajaran jarak jauh dirasa kurang efektif oleh peserta didik maupun guru sebagai tenaga pendidik.

Hal tersebut didukung oleh penelitian yang diperoleh Putri, Witriani \& Cahyadi (2021), bahwa $71,29 \%$ dari 101 guru SMA di berbagai daerah Indonesia sebagai responden pada penelitian tersebut merasa bahwa kegiatan pembelajaran jarak jauh selama pandemi kurang efektif, sedangkan sisanya $28,71 \%$ guru lainnya menilai bahwa pembelajaran jarak jauh cukup efektif. Alasan yang disampaikan cukup beragam. Namun yang menarik, alasan yang disampaikan oleh sebagian kecil responden yaitu diantaranya, siswa memiliki karakteristik mandiri, pendidik dapat menyampaikan materi dengan menarik, siswa berpartisipasi aktif, siswa mengerjakan tugas serta ujian, pendidik membangun interaksi dengan orang tua dan siswa, nilai ulangan tercapai, materi pembelajaran tersampaikan, keluarga berpartisipasi serta fasilitas menunjang. Akan tetapi, faktor yang menjadi alasan tersebut sangat sulit ditemukan secara keseluruhan. Salah satu dari berbagai macam alasan tersebut pasti akan ada yang tidak ditemukan, misalnya karakteristik peserta didik aktif tapi partisipasi keluarga dan fasilitasnya kurang menunjang, sehingga tetap dapat menjadi hambatan pada kegiatan belajar mengajar ketika tidak terdapat kekompakan antar faktor pendukung.

\section{Dampak Culture shock pada Peserta Didik dalam Pembelajaran Jarak Jauh}

Problematika pembelajaran jarak jauh dapat menjadi hambatan bagi peserta didik dalam membangun motivasi belajarnya. Menurut Uno dalam Ibrahim (2015) motivasi belajar dapat timbul akibat adanya faktor intrinsik dan ekstrinsik. Faktor intrinsik berasal dari dalam individu itu sendiri yang berupa hasrat, dorongan kebutuhan belajar, keinginan berhasil serta harapan akan cita-cita. Sedangkan faktor eksternal berasal dari luar diri individu yang berupa penghargaan, kegiatan belajar mengajar yang menarik, serta lingkungan yang kondusif. Dalam konteks pembelajaran jarak jauh, motivasi belajar setiap peserta tidak dapat diserahkan sepenuhnya kepada peserta didik semata.

Purba (2017) menjelaskan bahwa motivasi belajar merupakan proses yang mendorong peserta didik untuk melakukan kegiatan belajar, serta menjamin kelangsungan belajar agar tujuan peserta didik dapat tercapai. Motivasi belajar dapat dipengaruhi oleh perasaan negatif seperti cemas, bingung, curiga, marah dan takut terhadap lingkungan baru yang dimana hal 
ini merupakan komponen afektif dari dimensi culture shock. Komponen afektif ini mengacu pada perasaan yang dialami peserta didik ketika berada dalam lingkungan baru (Purba, 2017). Berdasarkan hal tersebut, motivasi belajar peserta didik akan terganggu apabila peserta didik tidak mampu beradaptasi dengan baik dan terus merasakan emosi negatif. Motivasi belajar yang menurun juga cenderung mendorong rasa malas, dan tidak aktif dalam belajar (Suryandari, 2012).

Fenomena culture shock pada peserta didik memang sangat berdampak negatif bagi kegiatan belajar peserta didik. Terlebih peserta didik tidak mampu memotivasi dirinya sendiri untuk melaksanakan pembelajaran secara aktif. Akan tetapi, resiko tinggi yang disebabkan oleh virus covid-19 mengakibatkan pembelajaran jarak jauh menjadi satu-satunya solusi yang tepat dalam kegiatan belajar mengajar dengan alasan dapat meminimalisir penyebaran virus tersebut. Meskipun tidak dapat dipungkiri bahwa pemberlakuan peraturan ini sempat mengalami penolakan dari berbagai kalangan, baik peserta didik maupun orangtua, dengan alasan yang beragam.

Keadaan culture shock pada peserta didik selama pembelajaran jarak jauh diduga akan tetap berlanjut meskipun telah memasuki pembelajaran secara tatap muka. Hal ini selaras dengan beberapa pernyataan dari pengamat pendidikan di Indonesia. Dikutip dari salah satu media daring, peserta didik yang masih mengalami culture shock dan belum bisa berdamai dengan hal tersebut, mereka akan menemui kendala bahkan setelah pembelajaran tatap muka sudah dimulai (Ayu, 2021). Peserta didik akan dihadapkan kembali dengan keadaan yang berbeda sehingga timbul perasaan dan kebiasaan yang berbeda.

Peserta didik akan dituntut untuk beradaptasi kembali dalam kegiatan belajar. Akibat dari keadaan tersebut bahkan bisa lebih buruk dari keadaan culture shock selama pembelajaran jarak jauh jika peserta didik tidak dapat beradaptasi dengan keadaan lingkungan yang baru. Hal tersebut terjadi karena perasaan yang dimiliki peserta didik belum stabil (Devinta, 2015). Culture shock lebih mudah mempengaruhi pengalaman lintas budaya di awal kembali diberlakukan pembelajaran tatap muka.

\section{Pentingnya Dukungan Orang Sekitar dalam Mengurangi Dampak Culture shock pada Peserta Didik dalam Pembelajaran Jarak Jauh}

Ketetapan peraturan pembelajaran jarak jauh yang dibuat pemerintah seharusnya dapat memunculkan kemandirian belajar. Studi sebelumnya menemukan bahwa hasil belajar peserta didik yang memiliki kemandirian belajar tinggi lebih baik daripada yang memiliki kemandirian belajar rendah (Pratama \& Pratiwi, 2019). Peserta didik yang memiliki kemandirian belajar yang tinggi akan cenderung lebih mudah dalam mengenal dan melakukan pengendalian diri yang ada pada diri sendiri bahkan orang lain. Sejalan dengan pendapat Nur (2014) bahwa kemandirian dan penyesuaian diri memiliki korelasi yang tinggi, dengan artian bahwa semakin tinggi tingkat kemandirian peserta didik akan semakin tinggi pula kemampuan peserta didik dalam menyesuaikan diri dengan lingkungannya. Namun, sayangnya tidak semua peserta didik memiliki kemampuan ini (Indrianie, 2012). Diperlukan dukungan orang sekitar selama pembelajaran jarak jauh.

Pertemanan sebenarnya mampu menurunkan akibat dari adanya gegar budaya ini. Seperti dinyatakan oleh Furnham (dalam Maizan, Bashori \& Hayati, 2020), relasi teman mampu membantu menyelesaikan dalam perpindahan budaya. Namun sayangnya kondisi ini menjadi lebih sulit ketika masa pandemi covid-19. Para peserta didik juga dinilai memiliki waktu membangun relasi pertemanan melalui bermain bersama. Oleh karena itu, peserta didik membutuhkan usaha berkali lipat untuk dapat menghadapi masa sulit seperti saat ini.

Lingkungan keluarga harus dapat memahami adanya culture shock pada peserta didik selama pembelajaran jarak jauh berlangsung. Keluarga perlu mendorong aktivitas belajar peserta didik agar terhindar dari perasaan negatif, seperti malas, frustasi, marah dan sebagainya. Sudah seyogyanya keluarga memberikan didikan dan bimbingan bagi anaknya (Anggraeni, 2018). Dalam konteks pembelajaran jarak jauh, orang tua perlu memberikan motivasi kepada anak-anaknya. Motivasi yang diberikan orangtua merupakan daya penguat 
diluar dari motivasi dalam diri peserta didik untuk membangkitkan gairah dan semangat belajarnya (Karmawan \& Bsep, 2012). Mengingat besarnya tanggung jawab orangtua terhadap pendidikan anak, maka dukungan yang diberikan orang tua akan sangat berperan terhadap keberhasilan pendidikan anak.

Dukungan yang diberikan dapat berupa dukungan moral maupun material. Adapun dukungan moral yang dapat diberikan kepada anak yaitu berupa perhatian terhadap kebutuhan psikis anak. Yang meliputi kasih sayang, bimbingan, pengarahan, keteladanan, serta dorongan dalam menanamkan rasa percaya diri. Dengan dipenuhinya kebutuhan psikis, anak diharapkan dapat memberikan semangat belajar (Hidayah, 2012). Sedangkan dukungan material berupa fasilitas belajar yang menunjang kegiatan pembelajaran jarak jauh. Terpenuhinya kebutuhan peserta didik tentunya akan membuat mereka merasa berharga, dan merasa dipedulikan. Selain itu, dukungan orangtua dapat memberi kenyamanan dan kesenangan tersendiri bagi kegiatan belajar mengajar walaupun dalam suasana pandemi. Dengan begitu peserta didik akan lebih semangat dalam belajar, itulah sebabnya hal tersebut akan membantu peserta didik dalam menumbuhkan motivasi belajar selama kegiatan pembelajaran jarak jauh berlangsung.

Guru sebagai tenaga pendidik juga memiliki peran yang cukup penting dalam menghalau culture shock pada peserta didik selama belajar dirumah. Dalam hal ini, pendidik dituntut untuk lebih kreatif, memiliki strategi serta metode pembelajaran yang menunjang seluruh kegiatan peserta didik. Baik dari segi fasilitas pembelajaran jarak jauh ataupun tingkat pemahaman siswa terhadap materi yang disampaikan. Selain itu, pendidik juga diharapkan dapat memberikan motivasi bagi peserta didik selama kegiatan pembelajaran jarak jauh berlangsung. Di awal proses pembelajaran, pendidik perlu mendiagnosa kondisi kelas dan peserta didik (Novariana, 2021). Diagnosa awal ini akan membantu pendidik dalam mencari alternatif strategi dalam meningkatkan motivasi belajar peserta didik di rumah.

Guru dapat menerapkan strategi interaksi edukatif pada daerah tempat tinggal peserta didik. Strategi ini dapat diterapkan pada peserta didik yang memiliki problematika pada proses pembelajaran jarak jauh seperti kurangnya fasilitas ekonomi sebagai penunjang kegiatan pembelajaran jarak jauh, juga kurangnya pemahaman peserta didik terhadap materi yang disampaikan secara daring, serta dengan syarat lingkungan peserta didik yang sudah aman. Sedangkan bagi peserta didik yang mampu memahami materi secara cepat, serta dukungan fasilitas yang menunjang, pendidik dapat menerapkan metode pembelajaran secara online dengan strategi yang dapat membangun rasa semangat belajar peserta didik. Selain itu, kolaborasi juga perlu diterapkan sebagai strategi pembelajaran.

Pendidik yang menerapkan pembelajaran kolaboratif, dapat melatih peserta didik dalam bertukar gagasan serta informasi dalam mencari solusi kreatif (Haspari \& Yonata, 2014). Berdasarkan hal tersebut kolaborasi tenaga pendidik dalam proses interaksi siswa saat pembelajaran jarak jauh sangat diperlukan, tenaga pendidik sesekali harus dapat berkolaborasi dengan peserta didik, salah satunya dengan cara mengerjakan tugas bersamasama agar peserta didik lebih antusias dalam melakukan proses pembelajaran, sehingga peserta didik tidak merasa stress dan dapat lebih termotivasi ketika pembelajaran jarak jauh berlangsung. Tidak hanya itu, pendidik juga dapat menyesuaikan platform yang dipilih berdasarkan situasi yang nyata ditempat peserta didik berada (Novariana, 2021). Hal tersebut penting untuk menunjang keefektifan belajar selama pandemi covid-19.

Untuk mengurangi gegar budaya dalam pembelajaran jarak jauh, komunikasi antara pendidik, peserta didik dan orang tua peserta didik adalah hal yang krusial. Studi sebelumnya menunjukan bahwa dibutuhkan strategi khusus oleh pendidik dalam menciptakan suasana belajar yang optimal (Vera, 2021). Hubungan antara orang tua dengan pendidik juga menjadi penting dalam masa pembelajaran jarak jauh (Fatahilah \& Sari, 2021). Mengingat orang tua dan pendidik memiliki peran dalam menumbuhkan budi pekerti pada peserta didik ketika belajar di rumah. 


\section{SIMPULAN DAN SARAN}

Berdasarkan hasil pembahasan tersebut dapat diambil kesimpulan bahwa kondisi culture shock pada peserta didik akibat pandemi menyebabkan peserta didik cenderung tidak aktif dalam melakukan kegiatan belajar mengajar. Fenomena ini disebabkan oleh keinginan peserta didik untuk pergi ke sekolah, belajar hingga bermain bersama namun tidak tercapai. Hal tersebut diprediksi mengurangi semangat peserta didik dalam melakukan kegiatan pembelajaran. Hal ini tentu harus menjadi perhatian bagi lingkungan keluarga untuk memberi dorongan dan motivasi terhadap kegiatan belajar peserta didik. Bukan tanpa sebab, orang tua merupakan unsur terpenting bagi pelaksanaan kegiatan pembelajaran jarak jauh. Orang tua harus sekondusif mungkin memberikan kenyamanan pada kegiatan belajar peserta didik, baik itu berupa dukungan, bimbingan, atau menyelaraskan keadaan. Dengan begitu, peserta didik akan terhindar dari perasaan bosan dan stres, sehingga pembelajaran jarak jauh akan terasa menyenangkan dan tidak berakibat menurunnya motivasi belajar. Selain itu, guru sebagai tenaga pendidik harus ikut serta dalam meningkatkan motivasi belajar peserta didik. Pendidik harus bisa memahami kondisi peserta didik, baik dari segi fasilitas, maupun kemampuan peserta didik terhadap mata pelajaran yang disampaikan. Hal tersebutlah yang kemudian dapat mempermudah pendidik dalam memilih alternatif kegiatan belajar yang tepat dan menyenangkan bagi seluruh peserta didik. Atas adanya keselarasan peran dari orangtua dan pendidik dalam kegiatan belajar mengajar akan semakin kondusif dan tidak berakibat terhadap turunnya motivasi belajar peserta didik. Dengan begitu peraturan pembelajaran jarak jauh yang dibuat pemerintah pun tidak perlu lagi dijadikan hambatan dalam kegiatan belajar mengajar, karena hal ini justru dapat menumbuhkan kemandirian peserta didik, sehingga kedepannya peserta didik akan lebih mudah menyesuaikan diri dalam melakukan kegiatan belajar mengajar.

Meskipun penulis menginginkan kesempurnaan dalam penyusunan tulisan ini akan tetapi pada akhirnya penulis menyadari kekurangan dalam tulisan ini yaitu artikel ini hanya menggunakan satu variabel yaitu culture shock. Kemudian, penulisan hanya menggunakan metode deskriptif sehingga data yang diambil tidak sepenuhnya relevan. Selain itu, solusi yang diberikan dalam artikel ini belum beragam terhadap fenomena problematika pembelajaran jarak jauh pada peserta didik. Adapun saran yang dapat penulis berikan adalah perlu adanya penambahan variabel, solusi, serta metode penelitian lebih lanjut akan upaya menanggulangi problematika pembelajaran jarak jauh yang dapat memicu culture shock kepada peserta didik.

\section{UCAPAN TERIMA KASIH}

Dalam kesempatan ini penulis memanjatkan rasa syukur kepada Allah SWT, karena kehendak dan ridha-Nya penulis dapat menyelesaikan artikel ini. Penulis juga mengucapkan terima kasih kepada teman-teman yang telah memberikan doa, dan dukungan kepada penulis untuk menyelesaikan artikel ini.

\section{DAFTAR PUSTAKA}

Anggraeni, N. F. (2018). Pengaruh Lingkungan Keluarga Terhadap Motivasi Belajar Siswa (Penelitian Deskriptif Kuantitatif Pada Siswa Kelas Iv Sekolah Dasar Kecamatan Lengkong Kota Bandung). 1, 16-72.

Asmuni, A. (2020). Problematika Pembelajaran Daring Di Masa Pandemi Covid-19 Dan Solusi Pemecahannya. Jurnal Paedagogy, 7(4), 281. Https://Doi.Org/10.33394/Jp.V7i4.2941

Siregar, A.O.A \& Kustanti, E.R. (2018). Hubungan antara gegar budaya dengan penyesuaian diri pada mahasiswa bersuku Minang di Universitas Diponegoro. Jurnal Empati, Volume 7 (Nomor 2), halaman

Astriyani, Y. \& Marzuki, I. (2021). PJJ: Digital Transformasi Daring Pada Evaluasi Pendidikan Di Era Pandemi Covid -19. 
Az-Zahra, D.A. (2021). Problematika pembelajaran daring, akademisi: Siswa dan pendidik alami culture shock. Diakses dari https://seputarsurabaya.jurnalisindonesia.id/read/12787/Problematika-PembelajaranDaring-Akademisi-Siswa-dan-Tenaga-Pendidik-Alami-Shock-Culture

Basri, C. N., \& Ridha, A. A. (2020). Gegar Budaya dan Motivasi Belajar pada Mahasiswa yang Merantau di Kota Makassar. Psikologika: Jurnal Pemikiran dan Penelitian Psikologi, 25(1), 1-14.

Bilfaqih, Y., \& Qomarudin, M. N. (2015). Esensi Pengembangan Pembelajaran Daring. In Deepublish. January 1.

Chafsoh, A. M. (2020). Munculnya Culture Shock Pada Mahasiswa Baru Dalam Perkuliahan Daring Selama Pandemi Covid-19. Jurnal Sejarah Artikel, 2-3.

Deny. (2020). Covid-19, culture shock di sekolah dan pesantren. diakses dari : https://suyanto.id/covid-19-culture-shock-di-sekolah-dan-pesantren/

Dhini, R. R., Ahmad, S., \& Mukminin, A. (2021). Problematika pembelajaran jarak jauh di Madrasah Ibtidaiyah Al-Munawaroh Kota Jambi (Doctoral dissertation, UIN Sulthan Thaha Saifuddin Jambi).

Devinta, M., Hidayah, N., \& Hendrastomo, G. (2015). Fenomena Culture Shock (Gegar Budaya) Pada Mahasiswa Perantauan Di Yogyakarta Title. Jurnal Pendidikan Sosiologi 2015, 3(3), 42-52.

Devito, J. A. (2013). The Interpersonal Communication Book 13th Edition. Pearson.

Erindana, F. U. N., Nashori, H. F., \& Tasaufi, M. N. F. (2021). Penyesuaian Diri Dan Stres Akademik Mahasiswa Tahun Pertama. Motiva: Jurnal Psikologi, 4(1), 11-17. Http://Ejurnal.Untag-Smd.Ac.Id/Index.Php/Mv/Article/View/5303

Fatahillah, F., \& Sari, S. W. (2021). Perspektif orang tua dalam gerakan penumbuhan budi pekerti pada masa pandemi covid-19. Journal of Elementary School Education, 1(1), 2633.

Fuadi, M. H. (2018). Culture Shock Pada Mahasiswa Asal Riau di Surakarta. 67(6), 14-21.

Hayati, N. (2020). Pembelajaran Jarak Jauh Selama Pandemi di Pondok Pesantren Darunajah 2 Bogor. RESIPROKAL: Jurnal Riset Sosiologi Progresif Aktual, 2(2), 151-159

Hidayah, F. N. (2012). Hubungan Antara Dukungan Orang Tua Dengan Motivasi Belajar Siswa Di Sd Negeri Bumi I Laweyan Surakarta. July, 32.

Hutapea, B. (2014). Life Stress, Religiosity, And Personal Adjustment of Indonesian as International Students. Makara Human Behavior Studies in Asia, 18(1), 25. Https://Doi.Org/10.7454/Mssh.V18i1.3459

Ibrahim, A. S. (2015). Hubungan Antara Motivasi Belajar Dengan Perilaku Membolos Pada Siswa Kelas Viii Smp Batik Surakarta. Journal Of Chemical Information and Modeling, 53(9), 1689-1699.

Indrianie, E. (2012). Culture Adjustment Training Untuk Mengatasi Culture Shock Pada Mahasiswa Baru Yang Berasal Dari Luar Jawa Barat. Insan, 14(65), 149-158.

Karmawan, H., \& Bsep, D. (2012). Motivasi Belajar Siswa (Studi Di Sd Negeri 22 Mengkudu Kecamatan Teluk Keramat Kabupaten Sambas) Role Of Family In Improving Motivating Learn Student (Study At Sdn 22 Mengkudu In Up Stair Teluk Keramat District Of Sambas Regency) Program Studi Sosiolo. Jurnal Tesis Pmis-Untan-Pss, 1-9.

Maizan, S. H., Bashori, K., \& Hayati, E. N. (2020). Analytical Theory: Cultural Extension (Culture Shock). PSYCHO IDEA, Tahun 18. No.2

Mitasari, Z., \& Istikomayanti, Y. (2018). Hubungan Antara Culture Shock Dengan Hasil Belajar Mahasiswa Tahun Pertama. Jurnal Psikologi Pendidikan Dan Konseling: Jurnal Kajian Psikologi Pendidikan Dan Bimbingan Konseling, 4(2), 105. Https://Doi.Org/10.26858/Jpkk.V4i2.4316

Muttaqin, M. Z., Idris, U., KFrank, S. A., Ilham, I., Akhmad, A., \& Tibul, S. (2021). Cultural Shock of College Students on Facing Online Learning System During Pandemic Covid19 in Papua. ISSHE 2020 
Novariana, M. (2021). Interaksi Edukatif Guru Kunjung Sebagai Strategi Alternatif Meningkatkan Motivasi Belajar Dalam Pembelajaran Masa Pandemi Covid-19. Indonesian Journal of Educational Development, 1(4), 702-715. Https://Doi.Org/10.5281/Zenodo.4562072

Nur, A. R. (2014). Hubungan Antara Kemandirian Dengan Penyesuaian Diri Dalam Lingkungan Kampus Pada Mahasiswa.

Pramudiana, I. D., \& Setyorini, T. D. (2019). Hubungan antara gegar budaya dengan penyesuaian sosial siswa Papua di Magelang. Praxis: Jurnal Sains, Teknologi, Masyarakat dan Jejaring, 1(2), 125-138.

Pratama, R. A., \& Pratiwi, I. M. (2019). Hasil Belajar Sejarah Indonesia Melalui Pembelajaran Aktif Tipe Everyone Is A Teacher Here Berdasarkan Kemandirian Belajar. Sosial Horizon: Jurnal Pendidikan Sosial, 6(1), 96-107.

Purba, I. K. (2017). Hubungan Culture Shock Dengan Motivasi Belajar Pada Mahasiswa Perantau Universitas Sumatera Utara Angkatan 2016 Yang Berasal Dari Luar Pulau Sumatera. Https://Www.Usu.Ac.Id/ld/Fakultas.Html

Putri, B. A., Witriani, W., \& Cahyadi, S. (2021). Perspektif Guru Mengenai Efektivitas Pembelajaran Jarak Jauh Di Sma Saat Awal Pandemi Covid-19. Jisip (Jurnal IImu Sosial Dan Pendidikan), 5(3), 128-136. Https://Doi.Org/10.36312/Jisip.V5i3.2094

Salamah, I. (2016). Culture Shock Dan Strategi Coping Pada Mahasiswa Asing (Studi Kasus Pada Mahasiswa Asing Program Darmasiswa Samarinda). Psikoborneo, 4(4), 857-867.

Sinarti. (2017). IImu Komunikasi Fakultas Dakwah Dan Komunikasi Universitas Islam Negeri Alauddin Makassar 2017. 50700113127.

Siwi Haspari, N., \& Yonata, B. (2014). Group Discussion' S Cooperation Skill of The Student. Unesa Journal of Chemical Education, 3(2), 181-188.

Suryandari, N. (2012). Culture Shock Communication Mahasiswa. Jurnal IImu Komunikasi, 5.

Ufairoh, F. N., Paraswati, F., Imani, K., \& Nagari, P. M. (2021). Penyesuaian Diri Mahasiswa Akibat Culture Shock Pada Perubahan Sistem Pembelajaran di Era Pandemi. In Prosiding National Seminar on Accounting, Finance, and Economics (NSAFE) (Vol. 1, No. 4).

Vera, N. (2020). Strategi Komunikasi Dosen Dan Mahasiswa Dalam Meningkatkan Kualitas Pembelajaran Daring Selama Pandemic Covid-19. Avant Garde, 8(2), 165-177.

Zulela, \& Primasari, I. F. N. D. (2021). Kendala Pembelajaran Jarak Jauh (Pji) Secara Online Selama Masa Pandemik Covid-19 Di Sekolah Dasar. Jikap Pgsd: Jurnal IImiah IImu Kependidikan, 5(1), 64-73. 